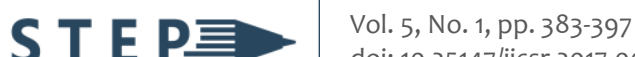 \\ doi: 10.25147/ijcsr.2017.001.1.47 \\ https://stepacademic.net
}

\section{Short Paper \\ The Impact and Effectiveness of E-Learning on Teaching and Learning}

\author{
Riah F. Elcullada Encarnacion \\ Tourism and Hospitality Department, Oman Tourism College \\ riah.encarnacion@otc.edu.om \\ (corresponding author) \\ Annjeannette Alain D. Galang \\ Department of Computer Science, Mariano Marcos State University \\ aadgalang@mmsu.edu.ph \\ Byron Joseph A. Hallar \\ BSIT Department, Mariano Marcos State University \\ bjahallar@mmsu.edu.ph
}

Date received: October 31, 2019

Date received in revised form: June 29, 2020

Date accepted: June 30, 2020

Recommended citation:

Encarnacion, R. E., Galang, A. D., \& Hallar, B. A. (2021). The impact and effectiveness of e-learning on teaching and learning. International Journal of Computing Sciences Research, 5(1), 383-397. doi: 10.25147/ijcsr.2017.001.1.47

\begin{abstract}
Purpose - This paper presents research findings on the effectiveness and impact of ELearning to the teaching and learning process of the Undergraduate Program (UGP) and General Foundation Program (GFP) at Oman Tourism College in Muscat, Sultanate of Oman.

Method - Teacher and student experience on E-Learning were evaluated by utilizing mixed methodology through online survey. Five criteria of effectiveness were established and used to assess E-Learning. The study determined the consensus measure and target consensus measure of teachers and students on the effectiveness of E-Learning employing the five factors. The study also examined whether students and teachers differ in their perceptions on E-Learning. The effects of E-Learning on teaching methodology and learning styles were also investigated.
\end{abstract}


Results - Teachers and students appeared to be in agreement on their perceptions on Elearning and provided higher ratings on E-Learning based on the five criteria of effectiveness. E-Learning was viewed favorably by teachers and students as an effective tool to enhance the delivery of instruction and develop knowledge acquisition skills through transfer of learning.

Conclusion -E-Learning can be considered as one of the best strategies to be adopted for teaching and learning. The researchers assert that the provision of education can no longer be restricted within a single campus but can be extended throughout the country through distance learning and integration of E-Learning solutions.

Recommendation - It is highly recommended that further study can be conducted to include other Higher Education Institutions in Oman in order to form a more concrete knowledge-based plan in creating E-Learning strategies.

Practical Implication - E-Learning could potentially shape the future of education by advancing the traditional classroom setting into the web. There is a need for the entire academic community to ensure that the factors of e-learning effectiveness are delivered adequately and the utilization of e-learning must be evaluated regularly.

Keywords: E-Learning, Learning Management System, Teaching Tool, Learning Styles, Teaching Methodology, Consensus Measure

\section{INTRODUCTION}

Higher education has dramatically evolved from traditional pedagogical models to current methods using computer technology that supports knowledge delivery and knowledge acquisition. The evolving technology has provided an opportunity to improve teaching skills and increase student's learning capabilities (Cappel \& Hayen, 2004; Filimban, 2008; Kirby, Sharpe \& Barbour, 2007). E-Learning is one example of evolving technology used in higher education.

E-Learning is a promising instructional medium as well as a ripe area in which to conduct investigation on its impact and effectiveness on student knowledge acquisition and teaching methodology. Many organizations adapt E-Learning to train employees while educational institutions use technology and internet to improve the quality of education (Simmons, 2002; Sahin \& Thompson, 2007; Selim, 2007). The trend of e-learning has put pressure among academic institutions to deliver courses on the Internet (Siragusa, 2002). However, there are many issues teachers and students encounter during the online teaching and learning process. With all the issues and the limited experience in an evolving technology, there is a pressing need to evaluate E-Learning to increase knowledge of its influence and effectiveness on educational activities. 


\section{LITERATURE REVIEW}

The integration of E-Learning has greatly expanded and improved the way of teaching and learning in higher education (Cappel \& Hayen 2004; Filimban 2008). According to Zaid (2009) "E-Learning is a term for all types of technology-enhanced learning (TEL), where technology is used to support the learning process". Many educational institutions implement E-Learning and utilize technologies experience tremendous impact and carve a niche in the field (Sahin \& Thompson 2007; Selim 2007). Some students who use ELearning have better learning performance and positive attitude (Kirby et al., 2007); others have been less positive about E-Learning due to difficulty of use, work load, lack of technological skills, and lack of face-to-face interactions (Picciano, 2002).

In order to develop a clear definition of what constitutes an effective E-Learning, it was necessary to review previous literatures as well as best practices in traditional and online teaching and collect the factors that best demonstrated successful E-Learning. An effective E-Learning environment is where the teacher actively provides quality course design and delivery (Rovai, 2002; Wright \& Lawson, 2005; Ally, 2008; Smith \& Ragan, 1999; Wakefield, 2009), implements appropriate assessments (Leshowitz et al., 1999; MacKnight, 2000; Siragusa, 2002), encourages collaboration (Murphy \& Cifuentes 2001; Tu \& Mclsaac, 2002; Garrison \& Anderson, 2003), and apply suitable teaching strategies to meet the needs of the students. Teachers are provided with technical support (Zhao, 2007; Haitham, 2009; Wang \& Wang, 2009) so that they can easily integrate teaching activities into the E-Learning system context (Cuban, 2001; Sonwalkar, 2002; Hayes, 2007). Students are given the opportunity to direct their own learning, gain experience with technology, establish connections with others, improve their critical thinking skills and apply them to real-life situations. In addition, they gain knowledge about themselves and the world around them, while mastering the course materials (Filimban, 2008). If courses are put online, students can study where and when they wish, tutors are freed from lecturing and classroom drudgery, and the institution can expand the courses offering to customers worldwide (Anderson, 2011).

In Omani higher education, the use of information technologies have been embraced largely by educational institutions and E-Learning has been viewed to bring education to the Omanis at a wide variety of locations. Several studies revealed a rapid adoption of course management system software utilization in Sultan Qaboos University and in College of Applied Sciences (Weber, 2010; Al-Musawi \& Abdelraheem, 2011).

\section{OBJECTIVES OF THE STUDY}

In Oman Tourism College (OTC), the use of Moodle as a Learning Management System began in 2014 with 20 undergraduate courses and 560 users, which increased in 2017 to 122 courses and offered to all students in the General Foundation Program and Undergraduate Program. As E-Learning in OTC is considered as an online tool for teaching and learning, the conduct of evaluation is indeed necessary to determine its impact and effectiveness. The study focused on the following research questions: 
1. According to teacher and student responses, how effective is E-Learning in OTC?

2. Is there a significant difference between the teachers and the students in their perceptions of the E-Learning?

3. How does e-learning affect teaching styles and learning styles?

\section{METHODOLOGY}

The E-learning of OTC was eventually named as Learn Online Portal (LOP) following its full implementation to the General Foundation Program (GFP) and Undergraduate Program (UGP) in 2017. The IT Department manages the LOP and an E-learning Administrator controls the Moodle administration. The LOP was successfully configured and linked to the Student Management System (SMS), the existing system of OTC. The active directory Lightweight Directory Access Protocol (LDAP) module was integrated to LOP for authentication of students and teachers' access. The e-learning courses are created based on the tutor plan uploaded in the SMS. The course teaching team prepares the teaching materials and the course coordinator manages the uploading of the course contents to LOP. The learning materials uploaded follow the module descriptor and module handbook. The e-learning courses created are then related to the specializations offered by the college. The General Foundation Program students are presented courses related to grammar, reading, writing, listening, and speaking while students in the undergraduate programs are enrolled in courses associated to their specializations on Tourism and Hospitality Management, Event Management, and Tourism Marketing. The e-learning courses are mainly used for blended and student-centered learning among students. Online content materials were available for download to any personal computers or mobile devices and were completed by students at their own pace. It is estimated that in the GFP, e-learning course is used by forty to sixty students while there are twenty to sixty students registered in every UGP e-learning courses.

With the successful implementation of LOP, an evaluation study using qualitative and quantitative methods (Creswell \& Miller, 2000; Johnson \& Onwuegbuzie, 2004; Brannen, 2005; Neuman, 2007) was conducted in the Fall Semester of 2019-2020 from August to December of 2019. The teachers and students of Oman Tourism College were the research participants to determine their perceptions on E-Learning based on the five criteria of effectiveness. This study used availability sampling or convenience sampling (Bless, Higson-Smith \& Kagee, 2006; Rubin \& Babbie, 2010). Research participants who volunteered for the study made themselves available during the data collection process and their responses were gathered using the Online Teacher Survey Questionnaire and Online Student Survey Questionnaire.

The survey questionnaires were made available using Survey Monkey which consisted of three sections: the first part was the demographic data composed of 4 questions related to gender, age, department, and specialization; the second part was the 
quantitative data on the factors of effectiveness and collected from the 10 item closeended questions of five-point Likert scale (1= Strongly Agree, 5= Strongly Disagree) statements in the survey; and the third part was the qualitative data gathered from an open-ended question on the impact of e-learning on teaching and learning. A pilot study was conducted to test the reliability and validity of the developed questionnaires (Cudeck \& O'Dell, 1994). Reliability analysis is important to measure the internal consistency of the variables in each factor (Santos, 1999) and this can be done using Cronbach's alpha (Cronbach, 1951). The value of the Cronbach's alpha should be as close as possible to 1 that indicates higher correlation among the variables. A commonly-accepted rule of thumb is that an alpha of 0.7 (some say 0.6 ) indicates acceptable reliability and 0.8 or higher indicates good reliability. Hence, it was decided to test the validity of all variables as well as each of the factors formed. The questionnaire was circulated among 42 respondents (20 teachers and 22 students), from various HEls in Muscat. The Cronbach's alpha for all variables result was 0.898 for Online Teacher Survey Questionnaire, and 0.877 for Student Survey Questionnaire, which was an acceptable level to proceed further with the study.

\section{RESULTS}

\section{Profile of the Research Participants}

There were 60 teachers and 162 students who participated in the study. Table 1 and Table 2 below present the profiles of research participants.

Table 1. Profile of the Teacher Participants

\begin{tabular}{|c|c|c|c|}
\hline Demographic & Variable & Frequency & Percentage \\
\hline \multirow[t]{2}{*}{ Gender } & Male & 45 & $75 \%$ \\
\hline & Female & 15 & $25 \%$ \\
\hline \multirow[t]{7}{*}{ Age } & $17-19$ & 0 & $0 \%$ \\
\hline & 20- 22 & 0 & $0 \%$ \\
\hline & $23-25$ & 4 & $7 \%$ \\
\hline & $26-28$ & 3 & $5 \%$ \\
\hline & $29-31$ & 4 & $7 \%$ \\
\hline & $32-34$ & 10 & $17 \%$ \\
\hline & 35 and above & 39 & $65 \%$ \\
\hline \multirow[t]{2}{*}{ Department } & General Foundation Program & 42 & $70 \%$ \\
\hline & Undergraduate Program & 18 & $30 \%$ \\
\hline \multirow[t]{5}{*}{ Specialization } & Foundation Program & 25 & $42 \%$ \\
\hline & Tourism and Hospitality Management & 15 & $25 \%$ \\
\hline & Event Management & 12 & $20 \%$ \\
\hline & Tourism Marketing & 8 & $13 \%$ \\
\hline & Total & 60 & $100 \%$ \\
\hline
\end{tabular}


Table 2. Profile of the of Student Participants

\begin{tabular}{llll}
\hline \multicolumn{1}{c}{ Demographic } & \multicolumn{1}{c}{ Variable } & Frequency & Percentage \\
\hline Gender & Male & 94 & $58 \%$ \\
Age & Female & 68 & $42 \%$ \\
& $17-19$ & 58 & $36 \%$ \\
& $20-22$ & 46 & $28 \%$ \\
& $23-25$ & 10 & $6 \%$ \\
& $26-28$ & 3 & $2 \%$ \\
\multirow{5}{*}{ Department } & $29-31$ & 4 & $2 \%$ \\
& $32-34$ & 2 & $1 \%$ \\
& 35 and above & 39 & $24 \%$ \\
& General Foundation Program & 100 & $62 \%$ \\
& Undergraduate Program & 62 & $38 \%$ \\
& Foundation Program & 100 & $62 \%$ \\
& Tourism and Hospitality & & \\
& Management & 32 & $20 \%$ \\
& Event Management & 20 & $12 \%$ \\
& Tourism Marketing & 10 & $6 \%$ \\
\hline
\end{tabular}

The quantitative data were analyzed using Excel and SPSS to provide a meaningful interpretation of data. From the teacher respondents, $70.00 \%$ were from the General Foundation Program and $30.00 \%$ from the Undergraduate Program. Meanwhile, from the student respondents who have completed the Online Student Survey, 38.00\% were from Undergraduate Program while 62\% were from the General Foundation Program.

\section{Teachers and Students Use of E-Learning}

The results of Online Teacher Survey provided information about the instructors' experience in designing E-Learning courses. When teachers were asked if they participated on developing an E-Learning course, a majority or $73.19 \%$ have answered "yes". Although teachers were active in E-Learning, many of them had only begun to develop E-Learning courses wherein a substantial percentage of $45.10 \%$ have designed two or more courses. Teachers in the General Foundation Program (GFP) mostly developed courses in Reading, Writing, and English Grammar yielding a percentage of $25.00 \%$ on each of the courses while the Introduction to Tourism and Hospitality course ranked the first, with 33.33\%, among the courses designed by Tourism and Hospitality Management (THM) lecturers in the Undergraduate Program.

The results of Online Student survey revealed that $95.00 \%$ of the students used ELearning because their teachers have been encouraging them to enroll between 2 - 3 courses (49.34\%). The course on English Grammar gathered the highest number of 
enrolled students (44.64\%) followed by Writing (16.07\%) and Reading courses (12.50\%). Juxtaposed to the result with courses developed by THM teachers, students mostly preferred the course on Introduction to Tourism and Hospitality (17.71\%).

\section{Strength of Agreement on the Effectiveness of E-Learning}

This study measured the effectiveness of E-Learning based on the factors of effectiveness including Content Quality, Assessment, Collaborative Environment, System Quality, and Technical Support. Two Likert-type statements were written for each criterion and responses were ranked on a scale of $1-5$ (Strongly Agree, Agree, Neutral, Disagree, and Strongly Disagree) to determine the strength of agreement among teachers and students. The Likert scale statements were treated as ordinal data and the results were analyzed using consensus and targeted consensus measurements (Tastle, Russell, \& Wierman, 2005; Tastle \& Tastle, 2005; Tastle, Wierman, \& Dumdum, 2005). Consensus is defined as general agreement among the members of a given group. Consensus measure can easily determine the proximity or distance of data to the unanimous agreement. Furthermore, the consensus measure can be extended to create targeted consensus by fixing the predetermined focal point to Strongly Agree and assigning it a value of 1 . Hence, Tastle and Tastle (2005) explained that:

"If the majority of the scores center around neutral or disagree, the focal point (SA) will be a greater distance...and the strength of consensus will be less (closer to 0 ). However, if the majority... are in strong agreement or agree, then the strength of consensus will be close to 1 " (p.3).

Thus, the strength of agreement measure (Tastle \& Wierman, 2010) was used to analyze and summarize the raw data of the surveys into two phases. The first phase was to produce a program level summary which included every teacher and student consensus and targeted agreement scores in a department. See Table 3.

Overall, the scores in each program resulted to be very similar. Teachers and students in the Undergraduate Program have provided higher ratings in each criterion. The slightly higher teacher responses received by Tourism and Hospitality Management in the Undergraduate Program were probably the result of good instructional design and highly active and engaging discussions. Likewise, the higher student ratings were possibly motivated by the design and quality of course materials and the provision of online assessment and student-centered activities. 
Table 3. Program Level Summary of Teacher and Student Agreement Measures

\begin{tabular}{|c|c|c|c|c|c|c|c|c|}
\hline \multirow[b]{2}{*}{ Criteria } & \multicolumn{4}{|c|}{ General Foundation Program } & \multicolumn{4}{|c|}{ Undergraduate Program } \\
\hline & *TCns & ${ }^{*} \mathrm{TCns}(\mathrm{t})$ & *SCns & ${ }^{*} \operatorname{SCns}(\mathrm{t})$ & TCns & $\operatorname{TCns}(\mathrm{t})$ & SCns & SCns(t) \\
\hline \multicolumn{9}{|l|}{ Content } \\
\hline Quality & 0.82 & 0.77 & 0.71 & 0.75 & 0.74 & 0.84 & 0.72 & 0.81 \\
\hline Assessment & 0.72 & 0.73 & 0.62 & 0.71 & 0.72 & 0.82 & 0.72 & 0.80 \\
\hline Collaborative & & & & & & & & \\
\hline $\begin{array}{l}\text { Environment } \\
\text { System }\end{array}$ & 0.79 & 0.77 & 0.64 & 0.77 & 0.77 & 0.87 & 0.70 & 0.78 \\
\hline $\begin{array}{l}\text { Quality } \\
\text { Technical }\end{array}$ & 0.73 & 0.75 & 0.64 & 0.75 & 0.78 & 0.83 & 0.71 & 0.80 \\
\hline Support & 0.72 & 0.75 & 0.65 & 0.75 & 0.66 & 0.74 & 0.67 & 0.76 \\
\hline \multicolumn{9}{|c|}{ * TCns - Teacher consensus score } \\
\hline \multicolumn{9}{|c|}{ * TCns $(t)$ - Teacher targeted consensus score } \\
\hline \multicolumn{9}{|c|}{ * SCns - Student consensus score } \\
\hline * SCns $(t)-$ Studer & targeted & sensus sco & & & & & & \\
\hline
\end{tabular}

The second phase was the college level summary that comprised the combined data from all students and teachers in the college to derive a broader overview in which the median scores were clearly visible. See Table 4.

Table 4 College Level Summary of Teacher and Student 4 Agreement Measures

\begin{tabular}{lrrrr}
\hline \multicolumn{1}{c}{ Criteria } & \multicolumn{4}{c}{ College Level Summary (GFP and UGP) } \\
*TCns & *TCns(t) & *SCns & *SCns(t) \\
\hline Content Quality & 0.81 & 0.79 & 0.72 & 0.79 \\
Assessment & 0.72 & 0.76 & 0.67 & 0.76 \\
Collaborative & & & & \\
Environment & 0.80 & 0.80 & 0.68 & 0.78 \\
System Quality & 0.75 & 0.78 & 0.68 & 0.78 \\
Technical Support & 0.70 & 0.75 & 0.66 & 0.76 \\
\hline
\end{tabular}

Teachers had a high degree of consensus in relation to Content Quality and Collaborative Environment while students rated their access to online content materials at satisfactory, Agree, level.

\section{Significant Difference on the Perceptions on E-Learning}

The Sign test, measuring the difference between two related groups, was applied to compare the evaluation scores of teachers and students in relation to each criterion (Gosling, 1995; Bland, 2000; Hill \& Lewicki, 2006). For the analysis of each criterion, statistical significance was identified as $p$-value $\leq 0.05$. For each department, teacher scores were determined if it were higher, lower, or the same as the student ratings. However, tied scores were excluded when computing for the Sign test. The Null 
Hypothesis (Ho) stated that there is no significant difference between teacher scores and student scores and further implies that teacher scores and student scores for one criterion are in agreement. The Alternate Hypothesis ( $\left.\mathrm{H}_{1}\right)$ was that teachers would score themselves higher than the students. See Table 5 . The result shows that all the p-values were above 0.05; therefore, the null hypothesis cannot be rejected because none of the scores are statistically significant. Students and teachers were largely in agreement and rated E-Learning very similarly.

Table 5. Sign-Test difference between Teacher and Student Response in Relation to 5 Criteria of Effectiveness

\begin{tabular}{|c|c|c|c|c|c|c|}
\hline \multirow[b]{2}{*}{ Criteria } & \multicolumn{4}{|c|}{ Number of Department / Program } & \multirow[b]{2}{*}{$\begin{array}{c}\mathrm{p}- \\
\text { value }\end{array}$} & \multirow[b]{2}{*}{ Remarks } \\
\hline & ${ }^{*} \mathrm{TchrS}>\mathrm{StC}$ & $*$ StC $>$ TchrS & $\begin{array}{l}\text { Dept } \\
\text { with } \\
\text { tied } \\
\text { rating }\end{array}$ & $\begin{array}{l}\text { total \# } \\
\text { Dept }\end{array}$ & & \\
\hline \multicolumn{7}{|l|}{ Content } \\
\hline Quality & 2 & 0 & 0 & 2 & 0.25 & Not Significant \\
\hline $\begin{array}{l}\text { Assessment } \\
\text { Collaborative }\end{array}$ & 1 & 0 & 1 & 2 & 0.50 & Not significant \\
\hline $\begin{array}{l}\text { Environment } \\
\text { System }\end{array}$ & 2 & 0 & 0 & 2 & 0.25 & Not significant \\
\hline $\begin{array}{l}\text { Quality } \\
\text { Technical }\end{array}$ & 2 & 0 & 0 & 2 & 0.25 & Not significant \\
\hline Support & 1 & 1 & 0 & 2 & 0.50 & Not significant \\
\hline
\end{tabular}

\section{Impact of E-Learning on Teaching Methods or Learning Styles}

A small majority of teachers, $31.43 \%$ (22 responses) reported that the online classes have had an impact on their teaching styles. Teachers have attested that the use of technology was considered the best tool that helped them to organize their learning materials and made their teaching style more interesting to the students. The availability and accessibility of the learning materials to students relieved teachers from additional tasks such as photocopying course materials. In addition, teachers felt that in designing materials they have become aware of many online resources.

A higher percentage of students, $76.54 \%$ (124 responses), said that with E-Learning they have become more interested to learn. Students were positive about the changes they have noticed in their learning styles. The use of E-Learning greatly helped students to improve their learning skills including analyzing and solving problems, answering online quizzes, and submitting assignments and projects. The integration of technology made them comfortable in using computer and web-based resources helped them explore more ideas and enrich their knowledge. Students have also appreciated the 
variety of materials presented in a very organized manner. Above all, students can study with the E-Learning courses at their own pace and help them become independent learners.

\section{DISCUSSION}

In general, teachers and students showed a high degree of agreement on the effectiveness of E-Learning and most of them felt a positive impact on their teaching and learning styles.

The quantitative data was summarized by program and college level. In the program level, criterion on Content Quality and Collaborative Environment received higher ratings due to teacher's commitment in developing excellent and appropriate courses that foster student-centered activities in the class. Students can gain access to these courses at their own convenience and help them develop discipline in studying their lessons. However, despite teacher's effort to promote collaboration, it was one of the criteria that had a lower consensus from the students when data was organized in the college level. Other factors with lower ratings were Assessment, System Quality, and Technical Support. Most teachers implemented blended learning approach in the classroom and E-Learning was used as a supplementary instructional delivery medium. With this, students simply perceived E-Learning as a tool to download learning materials, practice online exercises, uploading assignments and projects. Additionally, students felt that E-Learning needs more strategies that will allow them to share ideas with other students. It is also important to note that some of the respondents perceive assessments as only paperbased quizzes and exams. Further, students and teachers experience technical difficulties and they demand prompt technical support in such situation.

Teacher and student ratings appeared to be in agreement and remarkably similar when their responses were compared using Sign Test. It only implies that E-Learning is viewed as a potential online tool to promote effective teaching and quality learning. This is consistent with the positive findings in the literature (Saragusa, 2002; Filimban, 2008; Al-Musawi \& Abdelraheem, 2011). Majority of the students believed that teachers must be active and enthusiastic in developing course materials and initiate course discussion online (Ally, 2008; Saragusa, 2012). At the same time, teachers also demanded students' active participation and collaborative learning using the e-learning materials. Teachers should accommodate various learning styles and integration of greater range of media such as video lectures and movie excerpts while student utilize the course contents for their own blended learning (MacKnight, 2002; Filimban, 2008). Both teachers and students requested for provision of assessment scoring for student online works and a mechanism to evaluate the authenticity of students course projects, quizzes, and assignments such as Turnitin Software. And lastly teachers suggested for more workshops or trainings (Al-Musawi \& Abdelraheem, 2011) in instructional design to keep them aware of new E-Learning software applications while students requested for orientation and special workshops including timetable for Learn Online Portal. 


\section{CONCLUSIONS AND RECOMMENDATIONS}

The present study may have been limited in terms of duration, location, and number and type of participants, however, the research findings provide a valuable contribution to support and agree with the previous scholarly works (Saragusa, 2002; Filimban, 2008; Al-Musawi \& Abdelraheem, 2011; Noesgaard \& Orngreee, 2015). Every learning institution is unique and may have varied e-learning practices and program implementation, but nevertheless, the goal is to promote e-learning effectiveness and measuring its impact to teaching and learning is deemed essential. An effective e-learning must be able to achieve the course learning outcomes through transfer of knowledge, acquisition of skills, and development of competency. It motivates students and teachers to work in an interactive, supportive, collaborative, and resourceful learning environment (Noesgaard \& Orngreee, 2015).

Investigating the impact and effectiveness of E-Learning on teaching and learning at OTC was a successful endeavor. The researchers were able to prove that teachers and students appeared to be in agreement on their perceptions on E-learning and provided higher ratings on E-Learning based on the five criteria of effectiveness. E-Learning was viewed favorably by teachers and students as an effective tool to enhance the delivery of instruction and develop knowledge acquisition skills through transfer of learning. Likewise, teachers felt a very positive impact on their working styles when they were using E-Learning as part of face-to-face instruction. In the same manner, students are becoming motivated to learn independently and study their courses with greater responsibility. It also enhances collaboration. Therefore, E-Learning can be considered as one of the best strategies to be adopted for teaching and learning.

In conclusion, this research can further establish the effectiveness of E-Learning in Omani higher education. Researchers assert that the provision of education can no longer be restricted within a single campus but can be extended throughout the country through distance learning and integration of E-Learning solutions. There were evidences that the growth of E-Learning had taken place in private and public colleges and universities in Oman. With this, it is highly recommended that further study can be conducted to include other Higher Education Institutions in Oman in order to form a more concrete knowledge-based plan in creating E-Learning strategies. This then hopes to better and develop Omani students who can be globally competitive in the future thus raising the bar of excellence in the higher educational system.

\section{IMPLICATIONS}

Based on the results of the current study, it can be deduced that e-Learning could potentially shape the future of education by advancing the traditional classroom setting into the web. The use of e-Learning has dramatically increased over the years as teachers and students perceived its usefulness and felt the impact of e-learning to their teaching 
methodologies and learning styles. Therefore, there is a need for the entire academic community to ensure that the factors of e-learning effectiveness are delivered adequately and the utilization of e-learning must be evaluated regularly. Thus, E-Learning plays a pivotal role in ascertaining the success of online teaching and learning.

\section{ACKNOWLEDGEMENT}

The authors are grateful to Oman Tourism College and Mariano Marcos State University for the support extended during the course of this academic research to the teachers and students, who participated in the survey, the Academic Affairs Office and IT Department of OTC for the opportunity to conduct the study, and to MMSU for the intellectual guidance in further improvement of this research paper.

\section{REFERENCES}

Al-Musawi, A.S. \& Abdelraheem, A.Y. (2011). The status of e-learning in SQU horizon (209) (unpublished manuscript). Public Relations and Information Department, Sultan Qaboos University.

Ally, M. (2008). Theory and practice of online learning: Foundations of educational theory for online learning, (2nd edn.). Edmonton: AU Press, Athabasca University.

Anderson, T. (2011). Theory and practice of online learning (5th edn.). Edmonton, Canada: AU Press Athabasca University.

Bland, M. (2000). An introduction to medical statistics (4th edn.). Great Britain: Oxford Press.

Bless, C., Higson-Smith, C., \& Kagee, A. (2006). Fundamentals of social research methods: an African perspective (4th edn.). Cape Town, South Africa: Juta and Co. Ltd.

Brannen, J. (2005). Mixed methods research: A Discussion paper, NCRM Methods Review Paper. Retrieved on October 20, 2011, from ESRC National Centre for Research Methods.

Cappel, J. J., \& Hayen, R.L. (2004). Evaluating EeLearning: A case study. Journal of Computer Information Systems, 44(4), 49-54.

Creswell, J. W. \& Miller, D. L. (2000). Determining validity in qualitative inquiry. Theory into Practice, 39(3), 124-131.

Cronbach, L. J. (1951). Coefficient alpha and the internal structure of tests. Psychometrika, $16,297-334$.

Cuban, L. (2001). Oversold and underused: Computers in the classroom. USA:Harvard University Press.

Cudeck, R. \& O'Dell, L.L. (1994). Applications of standard error estimates in unrestricted factor analysis:Significant test for factor loading and correlations. Psychological Bulletin, 115, 475-487.

Filimban, G. (2008). Factors that contribute to the effectiveness of online learning technology at Oregon State University (unpublished manuscript). Retrieved October 25, 2011, from ScholarsArchive at Oregon State University Electronic Theses and Dissertations. 
Garrison, D. R., \& Anderson, T. (2003). E-Learning in the 21st century: A framework for research and practice. London: Routledge/Falmer.

Gosling, J. (1995). Introductory statistics. New York: Pascal Press

Haitham, (2009). E-learning and management information systems universities need both. elearn Magazine, 52(20), 23-32 .Retrieved February 27, 2012, from https://elearnmag.acm.org/archive.cfm?aid=1621693

Hayes, D.N.A. (2007). ICT and learning: Lessons from Australian classrooms. Computers \& Education, 49(2), 385-395. Elsevier Ltd. Retrieved July 25, 2020 from https://www.learntechlib.org/p/67366/.

Hill, T., \& Lewicki, P. (2006). Statistics: Methods and applications: A comprehensive reference for science, industry, and data mining. Tulsa, OK: StatSoft.

Johnson, R. B. \& Onwuegbuzie, A. J. (2004) Mixed methods research: A research paradigm whose time has come. Educational Researcher, 33(7), 14-26.

Kirby, D., Sharpe, D., \& Barbour, M. (2007). Student perceptions and preferences for tertiary online course: Does prior high school distance learning make a difference? In Proceedings of Annual Conference on European Open and Distance Learning. Retrieved February 27, 2012, from European Distance and E-Learning Network database.

Leshowitz, DiCerbo, K.E., and Symington, S. (1999). Effective thinking: An ActivE-Learning Course in critical thinking. Current Issues in Education, 2(5). Retrieved March 7, 2012 from http://cie.asu.edu/ojs/index.php/cieatasu/article/view/831

MacKnight, C. (2000). Teaching critical thinking through online discussions. Educause Quarterly, 23(4), 38-41. Retrieved October 8, 2011, from ERIC database.

Murphy, K. L. \&Cifuentes, L. (2001). Using web tools: Collaborating and learning online. Distance Education, 22(2), 285-306.

Neuman, W.L. (2006). Social research methods: Qualitative and quantitative approaches. United States of America: Allyn and Bacon.

Noesgaard, S., Orngree, R. (2015). The effectiveness of e-Learning: An explorative and integrative review of the definitions, methodologies and factors that promote elearning effectiveness. The Electronic Journal of eLearning,3(4), 278-290.

Picciano, A. (2002). Beyond student perceptions: Issues of interaction, presence, and performance in an online course. Journal of Asynchronous Learning Networks, 6(1), 21- 40.

Rovai, A. (2002). Building sense of community at a distance. International Review of Research in Open and Distance Learning (IRRODL), 3(1), 1-16.

Rubin, A., \& Babbie, E.R. (2010). Essential research methods for social work (2nd edn.). Belmont, CA: Brookes/Cole.

Sahin, I., \& Thompson, A. (2007). Analysis of predictive factors that influence faculty members technology adoption level. Journal of Technology and Teacher Education, 15(2), 167-190.

Santos, J. R. A. (1999). Cronbach's alpha: a tool for assessing the reliability of scales. Journal Extension, 37(2),1-4. Retrieved on February 2, 2018 from www.joe.org/joe/1999april/tt3.php 
Selim, H. M. (2007) Critical success factors for E-Learning acceptance: Confirmatory factor models. Computers \& Education,49(2),396-413.

Simmons, D. E. (2002). The forum report: E-Learning adoption rates and barriers. In A. Rossett (Ed.), The ASTD e-learning handbook (pp. 19-23). New York: McGraw-Hill.

Siragusa, L. (2002). Research into the effectiveness of online learning in higher education: Survey findings. In Proceedings Western Australian Institute for Educational Research Forum 2002. Retrieved February 24, 2012 from Western Australian Institute for Educational Research databases.

Smith, P. L. \& Ragan, T. J. (1999). Instructional design (2nd edn.). New York: John Wiley \& Sons, Inc.

Sonwalkar, N. (2002). A new methodology for evaluation: The pedagogical rating of online courses. Syllabus, 15(6), 18-21. Retrieved March 5, 2012, from ERIC database.

Tastle, J., \& Tastle, W. (2005). Extending the consensus measure: Analyzing ordinal data with respect to extrema. Information Systems Educational Journal, 4(72), 3-7. Retrieved from https://isedj.org/4/72/ISEDJ.4(72).Tastle.pdf

Tastle, W., \& Wierman, M. (2010). Enhancing e-business decision making: An application of consensus theory. In IGI Global, Breakthrough Discoveries in Information Technology Research: Advancing Trends (pp.110-122). Retrieved on March 7, 2012, from IGI Global.

Tastle, W., Wierman, M., \& Dumdum, R. (2005). Ranking ordinal scales using the consensus measure. Issues in Information Systems, 6(2), 96-102.

Tastle, W. J., Russell, J., \& Wierman, M. J. (2005). A new measure to analyze student performance using the Likert scale. In Proceedings of the 22nd annual conference on Information Systems Education (ISECON) (p. 2142).

Tu, C., \&Mclsaac, M. (2002). The relationship of social presence and interaction in online classes. The American Journal of Distance Education,16(3),131-150. Retrieved October 6, 2011, from Academic Search Premier database.

Wakefield, J. (2009). Instructional design and technology. Retrieved on February 24, 2012, from Jenny Wakefield Blogsite.

Wang. T., \& Wang, C. (2009). A system dynamic model of teacher's adoption of e-learning system by integration of environment variables and teacher's characteristics. In Proceedings of 27th International Conference of the System Dynamics Society. Retrieved February 24, 2012, from System Dynamic Society Conferences database.

Weber, A. (2010). Web-based learning in Qatar and the GCC states (unpublished manuscript). Retrieved on February 25, 2012, from Center for International and Regional Studies, Georgetown University, School of Foreign Service in Qatar.

Wright, E. R. \& Lawson, A.H. (2005). Computer mediated communication and student learning in large introductory sociology classes. Teaching Sociology,33(2),122-135.

Zaid, A. A., (2009).Using e-learning to facilitate 21st century learning. Retrieved on February 27, 2012 from slidehare database.

Zhao, Y.(2007). Social studies teachers' perspectives of technology integration. Journal of Technology and Teacher Education, 15(3), 311-333. 


\section{Author's Biography}

Dr. Riah F. Elcullada Encarnacion is a Senior Lecturer at Oman Tourism College (OTC), Muscat, Oman. She received her degree Doctor in Information Technology from St. Paul University Philippines in 2018. She has been working in the academe for almost 20 years. Currently, she is a Module Coordinator of IT-related courses and also administers the learning management system using Moodle. She is also involved in conducting training to maximize the utilization of online technologies of OTC. Her main research areas are eLearning, information system, and big data analytics.

Dr. Annjeannette Alain D. Galang is an Assistant Professor of the Mariano Marcos State University (MMSU), Batac City, Ilocos Norte, Philippines. She graduated with the degree of Doctor in Information Technology from Saint Paul University Philippines last 2017. With 17 years of experience in the academe, she teaches computer science and information technology courses at her university's Department of Computer Science and Graduate School. She is an active faculty researcher in the fields of information systems, big data and data analytics. Dr. Galang was also the former Program Coordinator her university's Master in Information Technology graduate program and is currently its Chief of Admissions.

Dr. Byron Joseph A. Hallar is an Assistant Professor of the Mariano Marcos State University (MMSU), Batac City, Ilocos Norte, Philippines. He earned the degree of Doctor in Information Technology from Saint Paul University Philippines in 2017. Involved in the academe since 1996, he teaches ICT courses at the tertiary and graduate level and is engaged in research activities that focus on mainly information technology, data mining and data analytics. As an administrator, he has also held the position of Department Chairperson of the university's Industrial Technology Department. At present, Dr. Hallar is the Chief of Distance Learning of the Mariano Marcos State University. 